\title{
The ages of zircons from the Jurassic sediments of Bluefish River slope, NWT Canada and the possible age of kimberlite activity on the Lena West property
}

\author{
A.M. Agashev ${ }^{1}$, S.S.Kuligin ${ }^{1}$, Y. Orihashi ${ }^{2}$, N.P. Pokhilenko ${ }^{1}$, M.A. Vavilov ${ }^{1}$ and D. Clarke $^{3}$ \\ ${ }^{1}$ Institute of Geology and Mineralogy SB RAS, Novosibirsk, Russia. (agashev@uiggm.nsc.ru) \\ ${ }^{2}$ Earthquake Research Institute, Tokyo University, Japan \\ ${ }^{3}$ Diamondex Resources LTD, Vancouver BC, Canada
}

This work is presents a study of zircons extracted from the heavy minerals fraction of a sedimentary rock sample with anomalously high contents of wellpreserved kimberlite indicator minerals (KIM). The sample was taken from the basal horizon of JurassicCretaceous sandstones on the slope of Bluefish River valley. The Bluefish River, located in the Northwest Territories (Canada) north of Great Bear Lake, is the right tributary of the Mackenzie River. The Bluefish River basin is a part of the large Lena West property that occupies an area of about $40000 \mathrm{~km}^{2}$. Based on available tectonic data (Rino et al, 2004; Wu et al, 2002), the area is situated within the Paleoproterozoic Hottah terrane and is separated from the Slave Craton to the east by Wopmay orogeny. The Lena West property represents the sedimentary basin of a stable platform, which is filled with a thick sequence of mainly continental Cambrian-Cretaceous sediments. The Bluefish area is dominated by undivided JurassicCretaceous rocks (clay shales, siltstones, and sandstones), which make up the Parsons Series and represent terrigenous sediments of the continental margin. Undivided Cambrian-Devonian rocks are exposed only at the lower reaches and in the immediate vicinity of the river valley. Glacial deposits are subordinate.

During prospecting of this area for diamonds, anomalously high contents of KIMs (primarily, Crpyrope and picroilmenite) were found in the alluvial samples of the middle part of the Bluefish River. Sedimentary rocks were sampled on the river slope in detail (Fig. 1). The highest KIM contents (hundreds of grains) were found in samples from the basal horizon of Jurassic- Cretaceous sandstones. The Jurassic basal horizon rests on the limonitized gray siltstones of the Devonian Hare Indian Formation. The basal horizon (about $30 \mathrm{~cm}$ thick) includes three lithologically diverse interbeds: quartz gravelstones (upper interbed), limonitized coarse-to medium-grained sandstones (middle interbed), and yellow-green clays with a small admixture of pebbly material (lower interbed).

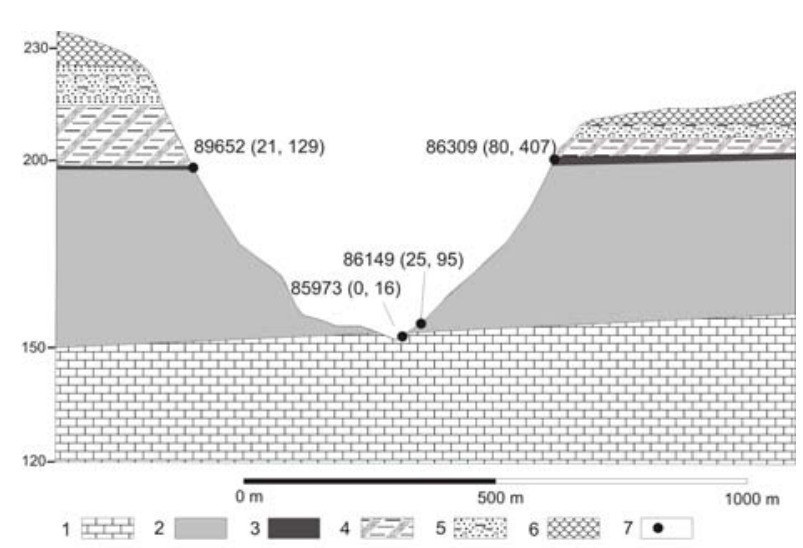

Fig 1. Section across sedimentary rocks in the Bluefish River valley. (1,2) Devonian: (1) limestones, (2) shales and siltstones of the Hare Indian Formation; (3-5) Jurassic-Cretaceous: (3) Jurassic basal horizon, (4) quartzite conglomerates and sandstones; (5) Gilmor Lake Formation: sandstones, siltstones, and shales; (6) Quaternary deposits; (7) sampling localities with sample numbers and amount of diamond-associated minerals (pyrope and picroilmenite) shown in parentheses.

\section{Sample and analytical method}

About 100 grains $(0.3-0.4 \mathrm{~mm}$ in size) were handpicked under binocular microscope from the heavy fraction of sample 86309 , and 30 grains were chosen for subsequent dating. The extracted zircons were analyzed for rare and rare-earth elements. Their $\mathrm{U}-\mathrm{Pb}$ isotopic composition was analyzed to determine the age of kimberlite activity and obtain information on geological evolution of the entire region. Analytical works were conducted using an inductively coupled plasma mass spectrometer and laser ablation for point dating at Tokyo University, Japan. Detailed description of analytical methods is given in (Orihashi et al, 2007). 


\section{Results and discussion}

The following results were obtained. Three grains from the sampling have an age ranging from Late Archean to Paleoproterozoic (2.7-2.3 Ga), indicating that the Hottah terrane was formed in the Archean and deformed in the Paleoproterozoic. This conclusion is supported by find of Archean zircons in the deltaic sands of the Mackenzie River, which outflows from Great Slave Lake and runs over an area devoid of Archean rocks. In particular, according to data (Rino et al, 2002), about $15 \%$ of 290 analyzed zircons from sandstones of the Mackenzie River delta have an age ranging from 2.5 to $3.4 \mathrm{Ga}$. The finds of diamonds and Cr-garnets of a diamond assemblage on the Lena West property suggest that the lithospheric mantle of the terrane possibly also has an Archean age and the lithosphere in the region is more than $150 \mathrm{~km}$ thick. The majority of zircons from the studied sampling is Paleoproterozoic in age varying within 1.95-1.8 Ga (Fig. 2). The obtained age corresponds to the timing of the Wopmay orogenic zone, which was formed during collision and amalgamation of the Hottah terrane to the Slave Craton (Zao et al, 2002). According to geochemical classification (Belousova et al, 2002), zircons were derived from carbonatite and dolerite sources. Magmatic rocks of the Great Bear zone confined to the Wopmay orogeny include carbonatealkaline and basic rocks ( $\mathrm{Wu}$ et al, 2002). The Paleoproterozoic tectonic stage is widely developed at the Siberian Craton. This is primarily the Akitkan orogenic belt related to the collision of the Aldan and Anabar cratons $1.85 \mathrm{Ga}$ ago, which produced the Siberian continent (Rosen et al, 1994). In turn, the Anabar Craton was formed from several Archean terranes $1.9 \mathrm{Ga}$ ago. One of these terranes (Olenek) possibly represents the continuation of the Hottah terrane, Northwestern Canada (Hoffman, 1991). The Paleoproterozoic global orogenic stage is also well manifested in the African continent. Of the 200 analyzed zircons taken from alluvium in the Kundelungi kimberlite field (Zair), about half of them have an age of $1.9 \mathrm{Ga}$ (Batumike et al, 2007), which corresponds to the timing of collision between the Kalahari and Kongo cratons and formation of the Katangan orogenic belt.

Only one of the analyzed zircons displays a Mesozoic age and can reflect the age of kimberlite activity in the Lena West property. In terms of geochemistry and the chondrite-normalized REE pattern (Fig. 3), this zircon can be classed as a kimberlitic type (Belousova et al, 2002), which differs from other zircons in the lower contents of Y, Hf, and HREE and the absence of an Eu anomaly. The age of this zircon is $164 \pm 6 \mathrm{Ma}$, which coincides with the Jurassic stage of kimberlite activity in the Siberian and Canadian kimberlitic provinces. In the Canadian province, this magmatism is primarily represented by the pipes of the Jericho cluster (northern Slave Craton) with an absolute age of $172 \mathrm{Ma}$ (Heaman et al, 2004). In the Siberian Craton, Jurassic kimberlite
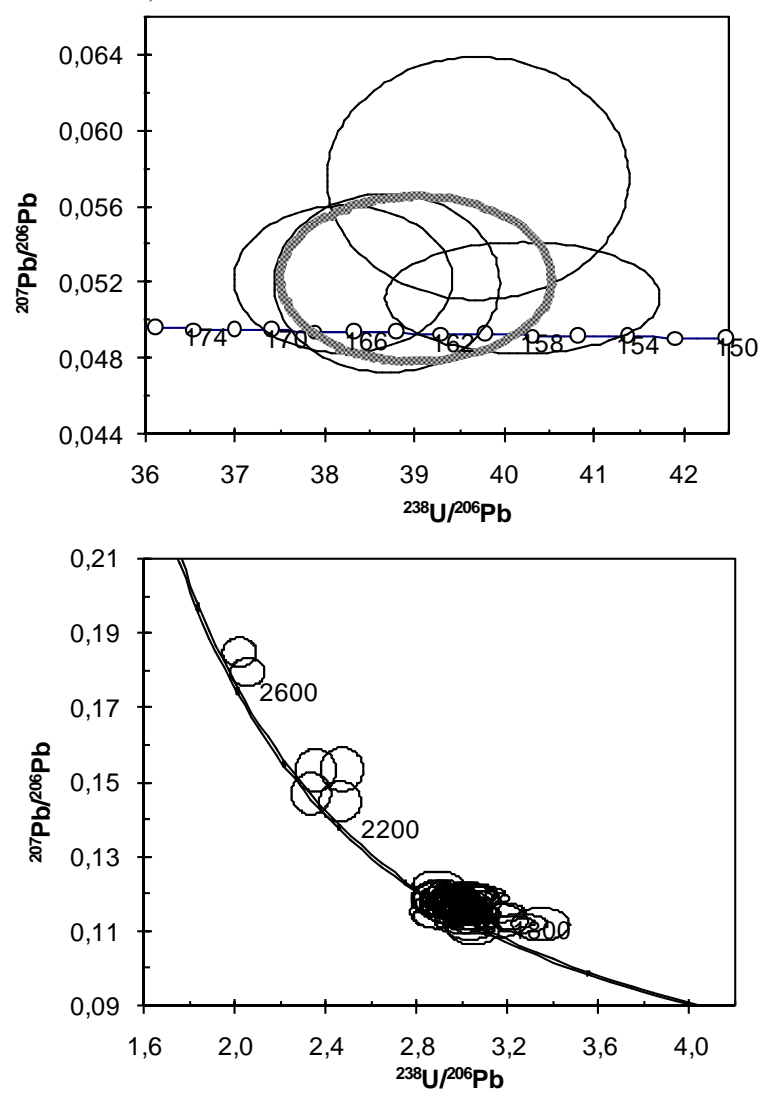

Fig 2. The Ages of zircons from sediments of Bluefish River slope. Upper plot is for kimberlitic zircon. The numbers along the lines indicate the age of reference points in millions years.

pipes are widespread within the Olenek terrane in the northern Yakutian diamondiferous province (Agashev et al, 2004). However, obtained result does not exclude that this area contains kimberlites of different ages (primarily, Middle Paleozoic). The Lena West property contains samples with anomalously high contents of well-preserved KIMs, which were taken within the domain of Devonian sediments and at a significant distance from undivided Jurassic-Cretaceous rocks.

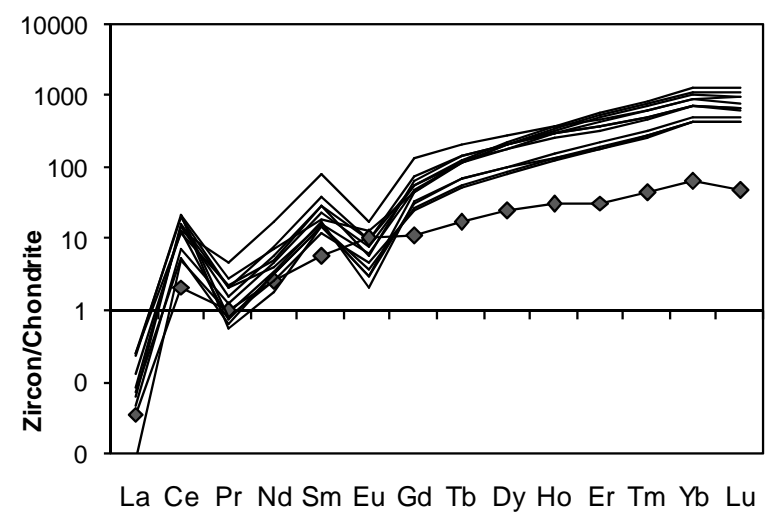

Fig 3. Chondrite normalised REE composition of zircons from sediments of Bluefish River slope, 
Canada. REE pattern of Kimberlitic zircon is indicated by diamonds.

\section{Conclusions}

Thus, the results of $\mathrm{U}-\mathrm{Pb}$ dating and geochemical study of zircons from the basal horizon of the JurassicCretaceous sandstones of the Bluefish River valley suggest the following conclusions: (1) the Lena West territory possibly has an Archean crystalline basement, which was strongly deformed in the Paleoproterozoic, and more than $150-\mathrm{km}$-thick lithosphere including depths corresponding to the diamond stability field; (2) the crystalline basement of the area was deformed during the Paleoproterozoic collision of the Hottah terrane with the Slave Craton and the formation of the Great Bear magmatic arc (Wopmay orogeny); (3) the studied territory existed as a stable platform since the Paleoproterozoic, with a minimum of tectonic and magmatic activity expressed in the accumulation of a thick sedimentary sequence; and (4) kimberlite activity in the Bluefish River region (Lena West property) occurred in the Jurassic. However, this does not mean an absence of kimberlites of different ages within this area.

\section{References}

Agashev, A.M., Pokhilenko, N.P., Tolstov, A.V., Polyanichko, V.V., Mal'kovets, V.G., Sobolev, N.V., 2004. New age data on kimberlites from the Yakutian diamondiferous province. Doklady Earth Sciences, 339, 1142-1145.

Batumike J.M., O'Reilly S.Y., Grifin W.L., Belousova E. A., 2007. U-Pb and $\mathrm{Hf}$ isotope analysis of zircon from the Kundelungu Kimberlites, D.R. Congo: Implication for crustal evolution. Precambrian Research, 156, 195-225.

Belousova E.A., Griffin W.L., O'Reilly S. Y., Fisher N.I., 2002. Igneous zircon: trace elements composition as an indicator of the source rock type. Contribution to Mineralogy and Petrology, 143, 602-622.

Heaman L.M., Kjarsgaard B.A., Creaser R.A., 2004. The temporal evolution of North American kimberlites. Lithos, 76, 377-397.

Hoffman, F.P., 1991. Did breakout of Laurentia turn Gondwana inside-out? Science, 252, 1409-1411.

Orihashi, Y., Nakai S., and Hirata, T., 2008. U-Pb age determinations for seven standard zircons by ICPMass Spectrometry coupled with frequency quintupled Nd-YAG $(\lambda=213 \mathrm{~nm})$ laser ablation system: Assessment to LA-ICP-MS zircon analyses with a NIST glass reference material. Resource Geology, 58, 101-123.

Rino, S., Komiya, T., Windley, B.F., Katayama, I., Motoki, A., Hirata T., 2004. Major episodic increases of continental crustal growth determined from zircon ages of river sands; implication for mantle overturn in Early Precambrian. Physics of the Earth and Planetary interiors, 146, 369-394.
Rosen, O.M., Condie, K.C., Natapov, L. M., Nozhkin, A. D., 1994. Archean to Early Proterozoic evolution of Siberian craton: a preliminary assessment. In: Condie, K.C. (Ed.), Archean Crustal Evolution. Elsevier, Amsterdam, pp. 411-459.

Wu, X., Ferguson I.J., Jones A.G., 2002. Magnetotelluric response and geoelectric structure of the Great Slave Lake shear zone. Earth and Planetary Science Letters, 196, 35-50.

Zhao G., Cawood P.A., Wilde S.A., Sun M., 2002. Review of global 2.1-1.8 Ga orogens: implication for pre-Rodinia supercontinent. Earth Science Reviews, 59, 125-162. 